INTERNATIONAL JOURNAL OF RESEARCHES IN BIOSCIENCES, AGRICULTURE AND TECHNOLOGY (C) VISHWASHANTI MULTIPURPOSE SOCIETY (Global Peace Multipurpose Society) R. No. MH-659/13(N) www.vmsindia.org

\title{
KINETICS AND MECHANISM OF SINGLE ELECTRON TRANSFER REDOX REACION OF NICOTINIC ACID HYDRAZIDES BY HEXACYANOFERRAE (III) IN ALKALINE MADIUM
}

\author{
S. V. Pore \\ Department of Chemistry, Bharati Vidyapeeth's Matoshari Bayabai Shripatrao Kadam Kanya Mahavidyalaya, \\ Kadegaon, Dist: Sangli (M.S ) India, 415304 \\ poresanjay67@gmail.com
}

\begin{abstract}
The kinetics and mechanism of oxidation of reactions between hexacyanoferrate (III) and Nicotinic acid hydrazide (NAH) were studied spectrophotometrically in sodium hydroxide medium under pseudo first order condition. The mechanism involves the formation of complex between the reactants, which decomposes in the subsequent step to give products. The reaction proceeds by direct one electron transfer with intervention of free radical and the order of reaction was found to be one with respect to hydrazide and hexacyanoferrate (III). The specific rate increases with an increase in the concentration of hydrazide and hexacyanoferrate (III). The salt that is ionic strength effect is positive ie addition of potassium chloride increases the rate of reaction, hence the reaction must be between species of the same charges. Increase in sodium hydroxide concentration increases the reaction rate and decreases with decrease in dielectric constant. The effect of temperature was studied between 25 to $45{ }^{\circ} \mathrm{C}$. The activation parameters were determined and the values support the proposed mechanism as evidenced by considerable decrease in entropy of activation.(- $\left.\Delta \mathrm{S}{ }^{\#}=26.45 \mathrm{~J} \mathrm{~K}^{-1} \mathrm{~mol}^{-1}\right)$ The progress of the reaction was followed by measuring the absorbance(A) of the hexacyanoferrate (III) at $420 \mathrm{~nm}$.
\end{abstract}

Keyw ords: $\mathrm{HCF}(\mathrm{III})$, NAH, hydrazides, kinetics, oxidation, redox reaction.

\section{Introduction:}

Hydrazides are physiologically active tested for their anti bacterial16, 23 biological activity 2 , anti inflammatory properties ${ }^{13}$, anti leprosy $\mathbf{8}^{\mathbf{8}}$, anticonvulsive action ${ }^{\mathbf{1 8}}$, anti-thelminities ${ }^{\mathbf{1}}$, to regulate and inhibit the growth of the plants ${ }^{\mathbf{2 4}}$, anti oxidants for poly olefins and polyurethanes. They have been extensively studied as a strong antituberculostatic agent.11 Some hydrazides are used in synthesis of certain amines, aldehydes and heterocyclic compounds. The applications of hydrazides and their derivatives in heat and corrosive stabilization of cellulose, applicability in plastics and cable insulation ${ }^{4}$, in sensitizing electrographic layers of polyvinyl carbazole ${ }^{\mathbf{7}}$, dihydrazides also used in cigarette filters for the removal of aldehydes from tobacco smoke. According to Haber and weiss ${ }^{9}$ oxidation is a simply a transfer of an electrons from reductant to oxidant and by considering number of electrons transferred to the oxidant during oxidative process, classification of the oxidation process as well as oxidants could be done ${ }^{15}$.The kinetics of oxidation of nicotinoyl and isonicotinoyl hydrazides by Iron(III) in the presence of $1: 10$ phenanthroline ${ }^{5}$ and the kinetics of $\mathrm{Ag}^{+}$ catalysed oxidation of nicotinic and iso-nicotinic acid hydrazides ${ }^{12}$ has been investigated.The study of the effect of position of Nicotinic acid hydrazide group on rate and mechanism of oxidation reaction, by $\mathrm{HCF}(\mathrm{III})$ is done in alkaline medium.

\section{Material and Method:}

The Nicotinic acid hydrazide (NAH) was prepared by reported procedure ${ }^{20}$ and stored in amber colored bottles kept in dark place. $\mathrm{K}_{3} \mathrm{Fe}(\mathrm{CN}) 6$, sodium hydroxide ,Potassium chloride and methanol used were of AR grade.

The double distilled water was used throughout the experiment. All possible precautions were taken to avoid the impurities. Their purity was checked after recrystallisation and from physical Constant $161^{\circ} \mathrm{C}$.

\section{Kinetic Procedure:}

2 Max for HCF(III) is Determined by measuring Absorbance of $5.0 \times 10^{-4} \mathrm{M}$ Solution of $\mathrm{HCF}$ (III) as a function of wavelength in range of 400-700 $\mathrm{nm}$, by using distilled water as reference. From the graph $\mathrm{HCF}(\mathrm{III})$ has a strong absorption at $420 \mathrm{~nm}^{3}$. Reaction were performed under pseudo-first order conditions: [hydrazide] $\geq \geq$ [ hexacyanoferrate (III) ] in a conical Pyrex glass ( coated black), thermo stated at $35^{\circ} \mathrm{c}$. The oxidation was initiated by adding a thermostated solution of hydrazide to a thermo stated solution of $\mathrm{HCF}$ (III) containing the required quantities of $\mathrm{NaOH}$. The progress of the reaction was followed by measuring the absorbance (A) of hexacyanoferrate (III) at 420 $\mathrm{nm}\left({ }^{\varepsilon}=1015 \quad \mathrm{dm}^{3} \quad \mathrm{~mol}^{-1} \mathrm{~cm}^{-1}\right)$ employing Spectronic 20 ( Milton Roy Company) and $1 \mathrm{~cm}$ path length cells.Pseudo- first order rate constants $(\mathrm{k})$ were evaluated using equation 1(3), which was valid to well over $70 \%$ disappearance of $\mathrm{HCF}(\mathrm{III}) . \mathrm{K}=(2.303 / \mathrm{t}) \log$ Ao/At --- (1) Where Ao and at are the absorbance at time Zero (initial) and $t$, respectively. The $\mathrm{k}$ values were in good agreement with those obtained from linear plots of $\log \mathrm{A}$ verses time. The second ordre $\mathrm{k}_{2}$ was 
calculated from the relationship $\mathrm{k} 2=\mathrm{k} 1 /$ [hydrazide ]o

\section{Stoichiometry and products:}

The Stoichiometry of the reaction was determined using known excess of $\mathrm{HCF}$ (III) over hydrazide concenteration and results consistent with following equation $\mathrm{NaOH}$
The Nicotinic acid was detected by paper chromatography ${ }^{3}$. The nitrogen was detected by lime tests ${ }^{21}$. The resultant mixture at the end of the reaction was rendered neutral after removal of $\mathrm{Fe}(\mathrm{CN}) 6^{4-}$. A test portion of neutral solution was added to an ignited mixture of lime and manganese dioxide $(10: 1)$ in a hard glass tube. The tube was heated and the liberated gas tested with manganese nitrate-silver nitrate paper, which showed grey flecks which turned blue immediately on treatment with a drop of benzidine solution, confirming the presence of nitrogen. The formation of carboxylic acids and $\mathrm{N}_{2}$ in the oxidation of aliphatic as well as aromatic acid hydrazides $\mathbf{1 0}$ is well documented in chemical literature. The formation of ammonia also takes place in addition to the formation of respective aryloxy acetic acid and nitrogen ${ }^{\mathbf{1 7}}$.

\section{Reaction Intermediates:}

The formation of free radical during the reaction was confirmed via neither induced polymerization of acrylonitrile nor reduction of $\mathrm{HgCl}_{2}$ occured in the absence of one of the two reactants.

\section{Result and Discussion:}

The reaction proceed with measurable velocity and shows the first order rate constant goes on slightly decreasing with the time. The plot of time in minute against optical density.(Fig.1)
The Effect of concentration of reactants [hexacyanoferrate (III) ]show that the order of reaction with respect to $\mathrm{HCF}$ (III) is one. The Effect of concentration of reactants [hydrazide] confirmed the first order behavior of the reaction w.r.t. Nicotinic acid hydrazide. The Effect of concentration of Alkali [NaOH] was found to be directly proportional to the concentration of sodium hydroxide.The Effect of Temperature used to calculate Activation parameters for the overall reaction evaluated from the Arrhenius and Eyring linear plots, are listed in Table 1.There was no effect of concentration of Salt $[\mathrm{KCl}]$ on the reaction rate.Effect of Dielectric Constant of the Medium [ $\left.\mathrm{CH}_{3} \mathrm{OH}\right]$ was negligible.

According to Haber and Weiss 9 is the stepwise transfer of an electron from reductant to oxidant. Thus traube and king 19 while studying the reaction of $\mathrm{CO}\left(\mathrm{NH}_{3}\right)_{5} \mathrm{Cl}^{2+}$ and $\mathrm{Cr}^{2+}$ in $\mathrm{HClO}_{4}$ solution, suggested the formation of $\mathrm{Cr}^{3+}$ which was found in the form of $\mathrm{CrCl}^{2+}$. They also obtained similar results for the very fast exchange of $\mathrm{Cr}^{2+}$ with $\mathrm{Cr}\left(\mathrm{H}_{2} \mathrm{O}\right)_{5} \mathrm{Cl}^{2+}$ in $\mathrm{HClO}_{4}$. Potassium ferricyanide falls into the class of oxidizing agents comprising ceric sulphate, ammonical silver nitrate and felhing's solution in all of which the oxidizing species is an electron abstracting ion. $\left[\mathrm{Fe}(\mathrm{CN})_{6}\right]^{3-}+\mathrm{e}^{-} \rightarrow$ $\left[\mathrm{Fe}(\mathrm{CN})_{6}\right]^{4-}$<smiles>CCCCCCCCCCCCC(=O)NN[NH3+]</smiles>

The RDS seems to be the transfer of an electron from anion to $\mathrm{Fe}(\mathrm{CN})^{3-6}$ ion,

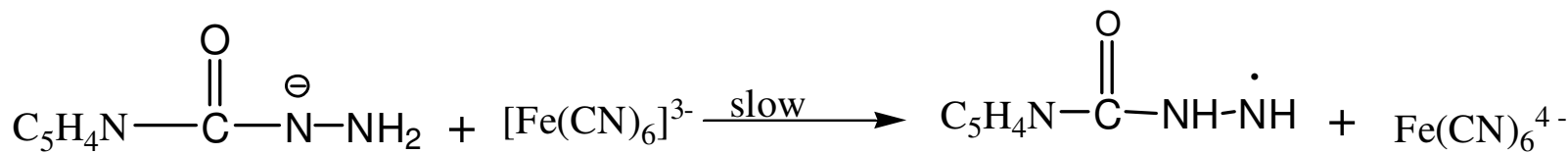

Frank and Krishna $\mathrm{Rao}^{5}$ have shown the formation of free radical in the oxidation of hydrazides by other reagents. The formation of free radical by electron transfer has shown by Haskar, Mehrotra and Ramachandra $\mathbf{1 0}$ 


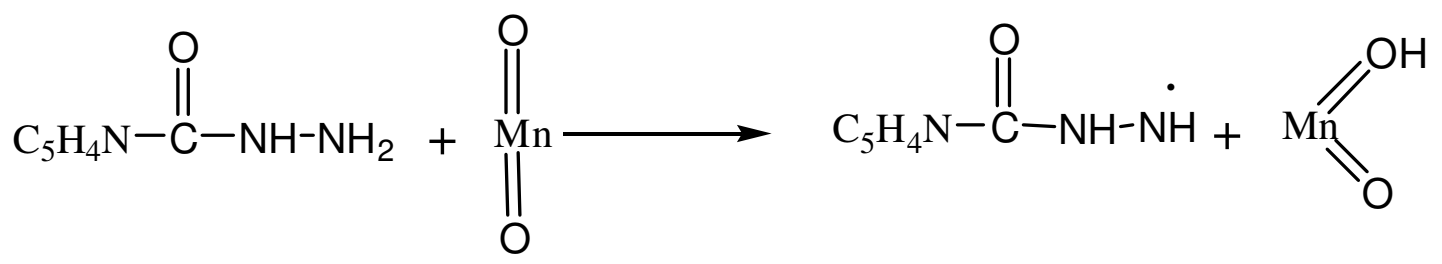

The mole ratio for this reaction is $1: 1$, The free radicals formed from the substrate undergo hydrolysis to produce carboxylic acid. ammonia and nitrogen. ${ }^{14}$
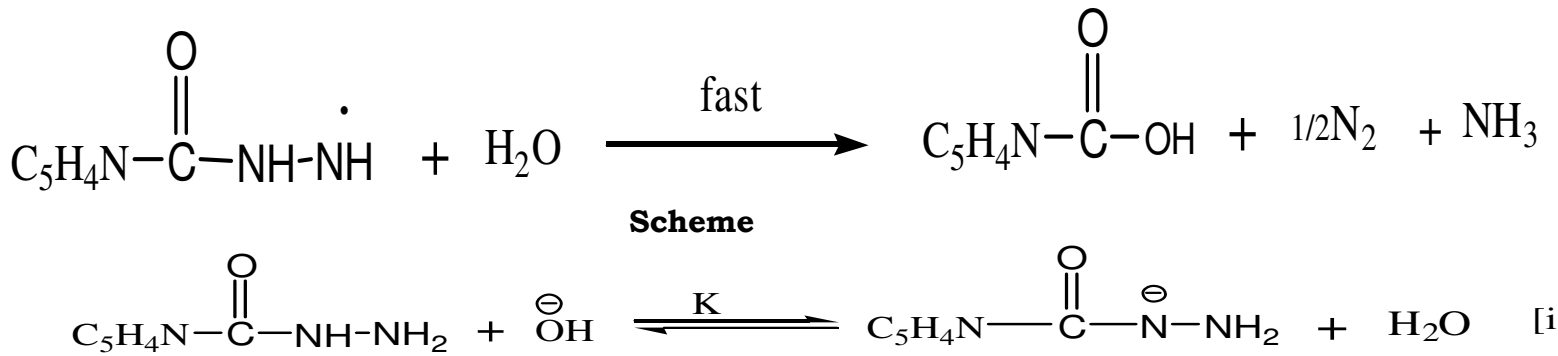

$\mathrm{C}_{5} \mathrm{H}_{4} \mathrm{~N}-\stackrel{\mathrm{O}}{\mathrm{C}}-\stackrel{\ominus}{\mathrm{N}}-\mathrm{NH}_{2}+\left[\mathrm{Fe}(\mathrm{CN})_{6}\right]^{3-} \frac{\mathrm{K}_{1}}{\text { slow }} \mathrm{C}_{5} \mathrm{H}_{4} \mathrm{~N}-\stackrel{\mathrm{C}}{-}-\mathrm{NH}-\dot{\mathrm{N}} \mathrm{H}+\mathrm{Fe}(\mathrm{CN})_{6}{ }^{4-}$

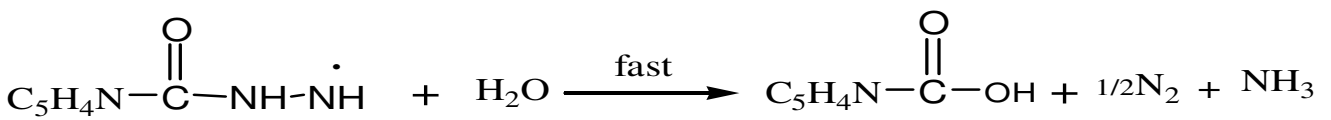

From step (ii) the rate of conversion of $\left[\mathrm{Fe}(\mathrm{CN})_{6}\right]^{-3}$ should be given by

$$
\frac{-\mathrm{d}\left[\operatorname{Fe}(\mathrm{CN})_{6}\right]^{3^{-}}}{\mathrm{dt}}=\mathrm{K}_{1}\left[\mathrm{C}_{5} \mathrm{H}_{4} \mathrm{~N}-\stackrel{\mathrm{O}}{\mathrm{C}}-\stackrel{\ominus}{\mathrm{N}}-\mathrm{NH}_{2}\right]\left[\operatorname{Fe}(\mathrm{CN})_{6}\right]^{3^{-}}
$$

[iv]

However, the equilibrium constant $\mathrm{k}$ for the first reaction can be written as:
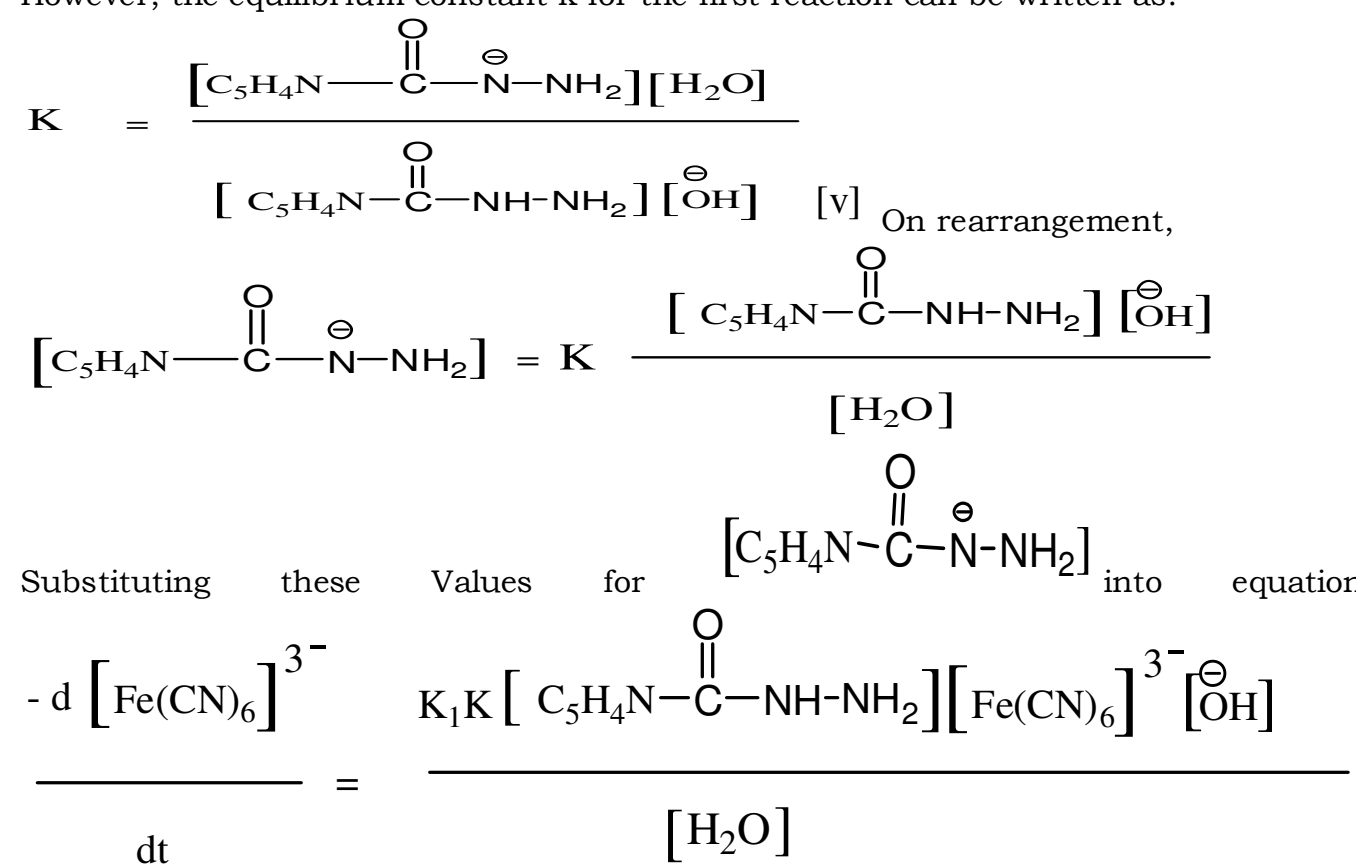
$\underbrace{=}_{\mathrm{d}\left[\mathrm{Fe}(\mathrm{CN})_{6}\right]^{3^{-}}} \mathrm{K} \quad\left[\mathrm{C}_{5} \mathrm{H}_{4} \mathrm{~N}-\stackrel{\mathrm{O}}{\mathrm{C}}-\mathrm{NH}^{-\mathrm{NH}_{2}}\right]\left[\mathrm{Fe}(\mathrm{CN})_{6}\right]^{3^{-}}[\stackrel{\ominus}{\mathrm{O} H}]$

[viii]

dt

$$
\text { Where } K=\frac{K_{1} K}{\mathrm{H}_{2} \mathrm{O}}
$$

Table No.1: Effect of Temperature :

\begin{tabular}{|c|c|c|c|c|c|c|}
\hline Temp in ${ }^{\circ} \mathrm{C}$ & 25 & 30 & 35 & 40 & 45 & \\
\hline $\mathrm{Kx} 10^{2} \mathrm{~min}^{-1}$ & 0.638 & 0.860 & 1.26 & 1.71 & 2.49 & \\
\hline Temp in $\mathrm{T}\left(\mathrm{k}^{\circ}\right)$ & 298 & 303 & 308 & 313 & 318 & \\
\hline $1 / \mathrm{T} \times 10^{3}$ & 3.35 & 3.30 & 3.25 & 3.20 & 3.15 & \\
\hline $\mathrm{K}_{\mathrm{r}} \times 10^{2} \mathrm{~min}^{-1}$ & 0.638 & 0.860 & 1.26 & 1.71 & 2.49 & \\
\hline $\log \mathrm{K}_{\mathrm{r}}$ & -2.1952 & -2.0655 & -1.8996 & -1.7670 & -1.6038 & \\
\hline $\log \mathrm{K}_{\mathrm{r}} / \mathrm{kT} / \mathrm{h}$ & -14.9875 & -14.8650 & -14.7062 & -14.5806 & -14.4243 & Mean \\
\hline Temp Coefficient per $10^{\circ} \mathrm{C}$ & - & 1.98 & 1.99 & 1.98 & - & 1.98 \\
\hline Ea kcal $/ \mathrm{mol}^{-1}$ by Graph & - & - & 12.81 & - & - & 12.81 \\
\hline Ea kcal/ $\mathrm{mol}^{-1}$ by calculation & - & 12.46 & 12.97 & 12.30 & - & 12.91 \\
\hline$\Delta \mathrm{H}^{\#} \mathrm{kcal} / \mathrm{mol}^{-1}$ & - & - & 12.58 & - & - & 12.58 \\
\hline $\mathrm{A} \times 10^{5} \mathrm{sec}^{-1}$ & 3.109 & 2.93 & 3.034 & 2.94 & 3.10 & 3.021 \\
\hline$\Delta \mathrm{S}^{\#}$ e.u. & -26.37 & -26.50 & -26.45 & -26.53 & -26.41 & -26.45 \\
\hline$\Delta \mathrm{G}^{\#} \mathrm{kcal} / \mathrm{mol}^{-1}$ & 20.43 & 20.61 & 20.72 & 20.88 & 20.98 & 20.72 \\
\hline
\end{tabular}
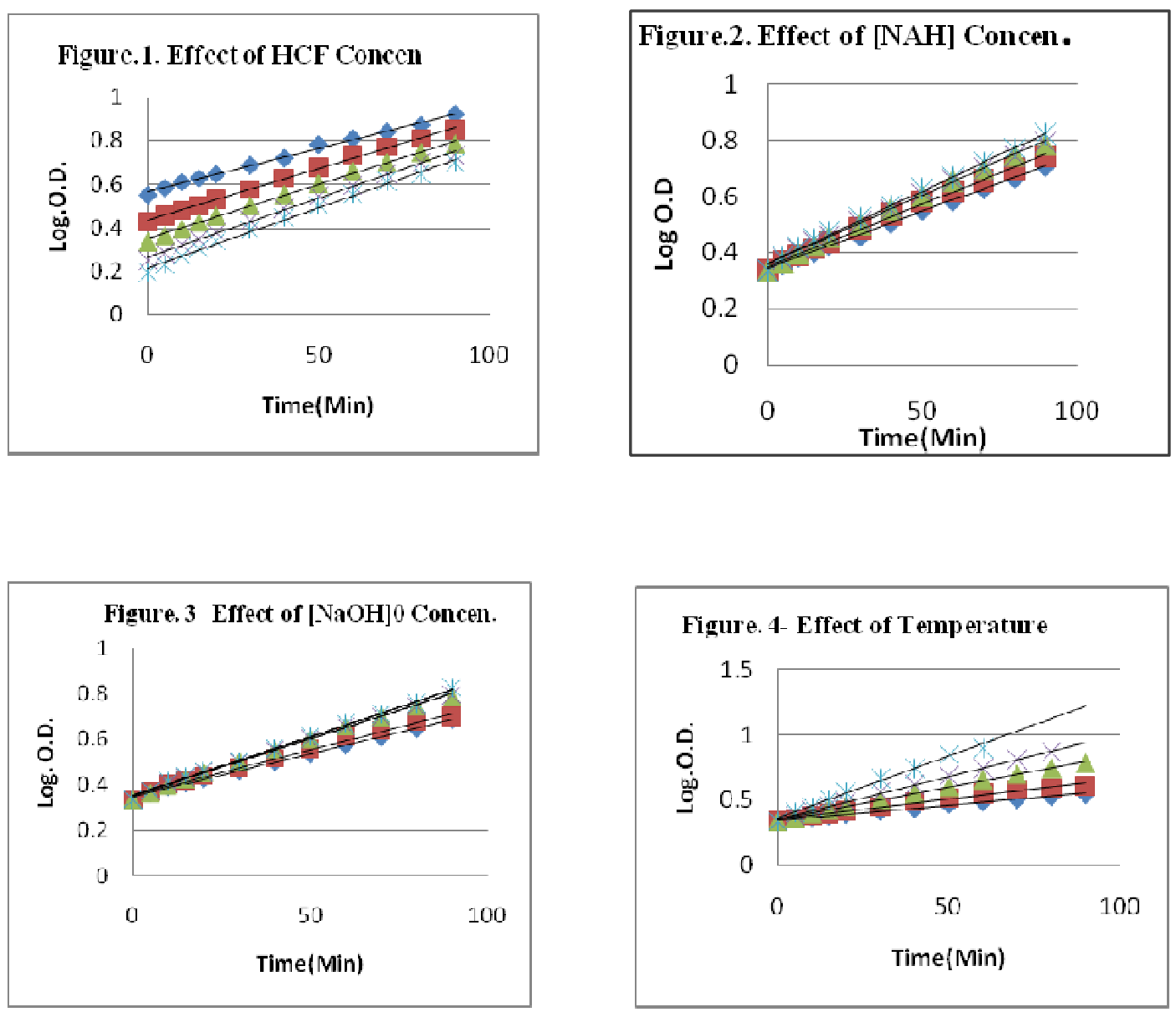


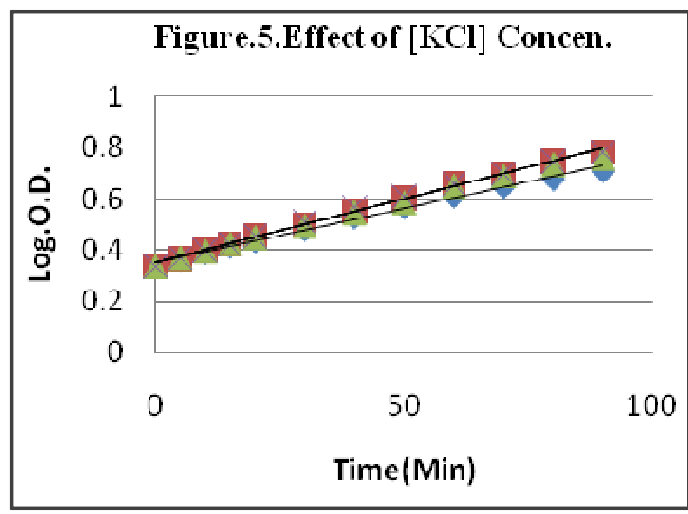

\section{Conclusion:}

The reaction is first order in substrate and oxidant. The specific rate is directly proportional to $[\mathrm{NaOH}]$. The large negative entropy $\Delta \mathrm{s} \not$, suggests the formation of a rigid transition state. While fairly high positive values of free energy of activation state is highly solvated. The effect of chloride ion concentration was found to be concentration dependent, indicates the reaction must be between species of the same charge. Allyl acetate $\mathbf{2 2}$ exerted an appreciable inhibitory effect on reaction rate indicates the free radical intermediate formation during the reaction and free radical is detected by acrylonltrlle test. The mole ratio is oxidant to substrate was found to be 1: 1 ,

\section{Acknowledgement:}

The author expresses his sincere thanks to UGC New.

\section{References:}

1. Cavier, R. and Rips, R. J., med. Chem.B.706 (1955)

2. Demetrescu, C., Chirita, C. and Ion, V, Pharm, Zntr. 107, 127 (1963)

3. Edgar, Chromatography. A review of principles and Applications, Elsevier, Amsterdam. 1957.

4. 150. Farben, Fabriken and bayer, A.G., Fr.Pat.1 450720 (1965)

5. Frank, M. S. and Krishnarao, P. V., Ind.J.Chem. 17A 632-4 (1979)

6. Fritz Feigl, Spot Tests in Organic analysis, $2^{\text {nd }}$ Ed.( Elsevier publishing Co. New York), 1972.

7. Gavaerst, photo production, N.V. British pat 988363 (1965) Chem.abst. 651962 F (1966).

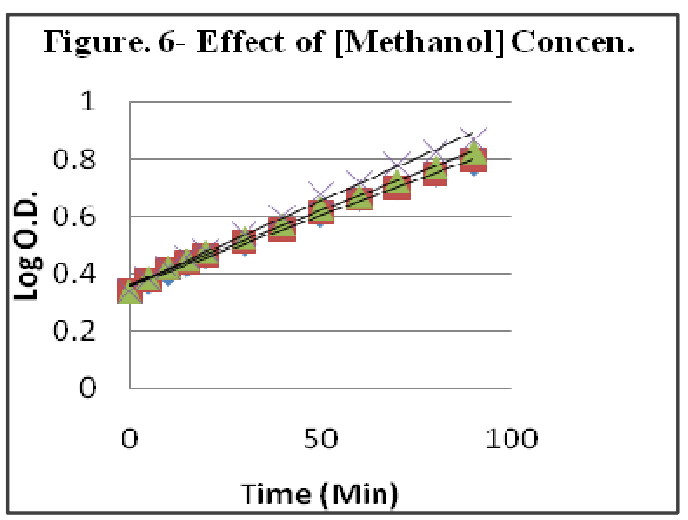

8. Gradner, T.S., Wenis. E and Lee, J. org.Chem.26, 1514 (1961).

9. Haber, F, and Weiss, J., Proc. Roy. Soc., 147, 322(1934).

10. Haskar, C.N., Mehrotra, R. C. and Ramchandran. P. K., Ind. J.Chem. 178, 191-2 (1979).

11. Hervey, L. R. B. and Tschrich, R. P., U.S. patent.3. 284, 234 (1966) Chem.Abst.66 12077 $\mathrm{F}$ (1967).

12. Hogale, M. B. and jagadale, M. H., Acta Ciencia indica meerut ( India), XC (3), 129 (1984).

13. Jucker, E., Linde and Nomann, A., Helv. Chem. Octa. 452316 (1962).

14.. Ladury. J. W. and Cullis, C. F. chemical Reviews, Vol. 58. 434 (1958).

15. Lel and Chinn, G. D., "Selection of oxidants in synthesis", oxidation at the carbon atom by Searle and co-chicago III inois.

16. Mahzhoyon, A. L., Armkhim, Z. H. ,19, 793 (1966).

17. Ramaiah, A. K, Frank M. S., BabuRao G. and Krishnarao P. V., Ind. J. Chem., 18 A (11), 416 (1976).

18. Renz, J., Bourquin, J. P. Winkler, $H$ and Bruiesch Weiler, C. Swiss, pat.419, 136 (1967) Chem. Abst.68.29709 (1968).

19. Traube H. and Kind, E. L., J. Am. Chem.Soc.76, 4053(1954).

20. Vogel A. I., A text book of Practical Organic Chemistry Including Qualitative Organic Analysis, 3rdEd. (E.L.B.S. and Longman Group Ltd.) (1975).

21. Vogel A. I., A text book of quantitative inorganic Analysis, Iv edn (E.L.B.S and Longman's green) 385C

22. Weiberg, K. B., J.Am,Chem.soc.81, 252(1959).

23. Winterstein, A., Hegedus, H, Fust, B., Bohni, E. and Studer, A., Helv, Chim. Acta. 39, 229, (1956).

24. Wood, B. R., Anal.Chem 25, 1879 (1953) 